\title{
HUBUNGAN PARITAS DAN KELAINAN LETAK DENGAN KEJADIAN KETUBAN PECAH DINI PADA IBU BERSALIN DI RSI GARAM KALIANGET
}

\author{
Sri Yunita Suraida Salat \\ Program Studi Diploma Kebidanan Universitas Wiraraja \\ e-mail: Ita_shalat@yahoo.com
}

\begin{abstract}
ABSTRAK
Ketuban pecah dini atau yang dikenal dengan Prematur Rupture of Membrane (PROM) merupakan proses pecahnya selaput ketuban sebelum ibu memasuki fase melahirkan. Pada tahun 2013 di indonesia, dari semua kehamilan $35 \%$ mengalami kejadian Ketuban Pecah Dini (Depkes RI 2013). Adapun tujuan dilakukannnya penelitian ini untuk menganalisis Hubungan Antara Kelainan Letak Dan Paritas Dengan Kejadian Prematur Rupture of Membrane (PROM) pada Ibu yang melahirkan di Rumah Sakit Islam Garam Kalianget Kabupaten Sumenep Pada Tahun 2016.

Penelitian ini merupakan jenis penelitian survey diskriptif yang menggunakan pendekatan secara retrospektif. Populasinya adalah semua ibu melahirkan yang mengalami Prematur Rupture of Membrane di Rumah Sakit Islam Garam Kalianget pada tahun 2016 yang berjumlah 20 orang dengan sample menggunakan tehnik Total Sampling. Instrument yang digunakan pada penelitian ini adalah Checklist. Analisa data pada penelitian ini menggunakan Distribusi Frequensi.

Dari hasil penelitian menunjukkan bahwa sebagian besar ibu yang mengalami Ketuban Pecah Dini adalah multipara sebanyak 12 ibu bersalin (60\%), dan hampir seluruhnya yaitu $16 \mathrm{ibu}$ bersalin $(80 \%)$ letak janinnya adalah letak kepala dan hampir seluruhnya yaitu 16 ibu bersalin $(80 \%)$ mengalami ketuban pecah dini dalam usia kehamilan aterm

Dapat di simpulkan bahwa Ibu yang mengalami Ketuban Pecah Dini di sebabkan beberapa faktor yaitu Status Paritas, Letak Janin dan Usia Kehamiln. Adapun solusi yang bisa ditawarkan untuk mengurangi resiko terjadinya Prematur Rupture of Membrane yaitu dengan cara pemeriksaan kehamilan yang dilakukan secara rutin serta pendeteksian dini tentang faktor-faktor predisposisi yang bisa menyebabkan terjadinya Prematur Rupture of Membrane sehingga dapat dicegah terjadinya komplikasi yang dapat terjadi.
\end{abstract}

Kata Kunci : Ketuban Pecah Dini, Paritas, Letak Janin, Usia Kehamilan.

\section{PENDAHULUAN}

Dalam sebuah proses kehamilan, air ketuban merupakan bagian yang cukup penting bagi keberlangsungan hidup janin di dalam rahim. Keadaan air ketuban dalam rahim sangat mempengaruhi kondisis janin dalam rahim. Harapan utama dari setiap kehamilan adalah kehamilan dapat berlangsung $\mathrm{dg}$ aman dan diakhiri dengan proses persalinan. Namun dalam kehamilan kadang kala terjadi Prematur Rupture of Membrane.

Prematur Rupture of Membrane merupakan proses pecahnya selaput ketuban sebelum ibu memasuki fase melahirkan. Prematur Rupture of Membrane dapat meningkatkan morbiditas dan mortalitas dikarenakan Prematur Rupture of Membrane dapat menyebabkan penyulit kelahiran seperti infeksi dan prematur. Pada tahun 2013 di indonesia, dari semua kehamilan $35 \%$ mengalami kejadian Ketuban Pecah Dini (Depkes RI 2013). Berdasarkan Profil kesehatan Jawa Timur tahun 2013 di jawa timur kejadian Prematur Rupture of Membrane sebanyak $18 \%$ dari semua kehamilan, sedangkan di Rumah Sakit Islam Garam kalianget tercatat adanya pasien dengan kejadian Prematur Rupture of Membrane pada tahun 2015 sebanyak 79 kasus. Dan Di Rumah Sakit Islam Garam Kalianget pada bulan januari-april kejadian prematuritas pada ibu melahirkan yang mengalami Prematur Rupture of Membrane sebanyak 4 kasus (20\%) dari 20 Prematur Rupture of Membrane. (Medical Record Rumah Sakit Islam Garam Kalianget, januariapril 2015). 
Penyebab Utama dari Prematur Rupture of Membrane sampai saat ini masih belum ditemukan secara pasti, namun ada beberapa faktor yang merupakan faktor penyebab Prematur Rupture of Membrane antara lain : infeksi, disposisi janin, tingginya tekanan intra uterin atau overdistesi, trauma, multi graviditas (multipara), sevalo pelvic disproporsi, perdarahan antepartum, Inkompetensi servik, Poli hidramnion, Riwayat ketuban pecah dini sebelumnya dan lain-lain. (Nugroho, 2012).

Multigraviditas (paritas tinggi) dapat menyebabkan terjadinya Ketuban Pecah dini karena pada kehamilan yang terlalu sering akan meyebabkan tipisnya selaput ketuban sehingga akan menyebabkan ketuban lebih mudah pecah sebelum adanya tanda inpartu. Sedangkan pada kelainan letak (selain letak kepala) menyebabkan tidak adanya bagian janin yang dapat menutupi bagian Pintu Atas Panggul (PAP) secara rapat seghinggadapat menghalangi adanya tekanan yang cukup besar pada membran dibagian bawah yang memudahkan pecahnya selaput ketuban janin. (Nugroho, 2010).

Melihar faktor predisposisi ketuban pecah dini, Adapun solusi yang bisa ditawarkan untuk mengurangiresiko terjadinya Prematur Rupture of Membrane yaitu dengan cara pemeriksaan kehamilan yang dilakukan secara rutin serta pendeteksian dini tentang faktor-faktor predisposisi yang bisa menyebabkan terjadinya Prematur Rupture of Membrane sehingga dapat dicegah terjadinya komplikasi yang dapat terjadi.

\section{METODE}

Penelitian ini berjenis penelitian observasional Deskriptif dengan Sampel semua ibu melahirkan yang mengalami Prematur Rupture of Membranedi Rumah Sakit Islam Garam kalianget Pada tahun 2016 yang berjumlah 20 orang. Teknik sampling yang di gunakan adalah Total sampling. Variabel penelitian dalam penelitian ini yaitu: ketuban pecah dini, paritas dan kelainan letak.

Penelitian ini dilaksanakan di Di Rumah Sakit Islam Garam Kalianget yang beralamat di JL. Raya Kalianget No.1
Sumenep-Madura dan waktu penelitian ini dilaksanakan mulai mulai Oktober 2017

Pengumpulan data menggunakan lembar cheklist. Data yang terkumpul akan dianalisis dengan cara tabel distribusi frekuensi dan presentase padasetiap variabel.

\section{HASIL PENELITIAN}

\section{Distribusi Frekuensi Paritas}

Tabel 1. Distribusi Frekuensi Berdasarkan status paritas pada ibu melahirkan dengan Prematur Rupture of Membrane Di Rumah Sakit Islam Garam Kalianget Pada tahun 2016.

\begin{tabular}{clcc}
\hline No. & Status paritas & F & $\%$ \\
\hline 1 & Primipara & 6 & 30 \\
2 & Multipara & 12 & 60 \\
3 & Grandemultipara & 2 & 10 \\
\hline & Jumlah & 20 & 100
\end{tabular}

Dari tabel 1 kita dapat melihat bahwa dari 20 ibu melahirkan yang mengalami kejadian Prematur Rupture of Membrane di Rumah Sakit Islam Garam Kalianget Pada tahun 2016 sebagian besar yaitu 12 ibu melahirkan $(60 \%)$ adalah multipara.

\section{Letak Janin.}

Tabel 2. Distribusi Frekuensi Berdasarkan letak janin ibu melahirkan dengan Prematur Rupture of Membrane Di Rumah Sakit Islam Garam Kalianget Pada tahun 2016.

\begin{tabular}{clcc}
\hline No & \multicolumn{1}{c}{ Letak Janin } & F & $(\mathbf{\% )}$ \\
\hline 1 & Bukan Letak kepala & 4 & 20 \\
2 & Letak kepala & 16 & 80 \\
\hline & Total & 20 & 100
\end{tabular}

Melihat tabel 2 dapat diketahui bahwa dari 20 ibu melahirkan yang mengalami kejadian Prematur Rupture of Membrane Di Rumah Sakit Islam Garam Kalianget Pada tahun 2016 hampir seluruhnya yaitu 16 ibu melahirkan (80\%) letak janinnya adalah letak kepala.

\section{Pengetahuan}

Tabel 3 Distribusi Frekuensi Berdasarkan kejadian Prematur Rupture of Membrane Pada Ibu Melahirkan Di Rumah Sakit Islam Garam Kalianget Pada tahun 2016.

\begin{tabular}{clcc}
\hline No & Ketuban Pecah Dini & F & \% \\
\hline 1 & Usia kehamilan aterm & 16 & 80 \\
2 & Usia kehamilan preterm & 4 & 20 \\
\hline & Jumlah & 20 & 100 \\
\hline
\end{tabular}


Pada tabel 3 diatas dapat diketahui bahwa dari 20 ibu melahirkan yang mengalami Prematur Rupture of Membrane Di Rumah Sakit Islam Garam Kalianget Pada Bulan Januari-April 2015 hampir seluruhnya yaitu 16 ibu melahirkan (80\%) mengalami ketuban pecah dini dalam usia kehamilan aterm.

\section{Tabulasi Silang}

Tabulasi silang Antara Paritas dengan Kejadian Prematur Rupture of Membrane Tabel 4. Tabulasi Silang Antara Paritas dengan Kejadian Prematur Rupture of Membrane Pada Ibu Melahirkan Di Rumah Sakit Islam Garam Kalianget Pada tahun 2016

\begin{tabular}{|c|c|c|c|c|c|c|c|}
\hline \multirow{3}{*}{$\begin{array}{l}\mathrm{N} \\
\mathrm{o} .\end{array}$} & \multirow{3}{*}{ Paritas } & \multicolumn{4}{|c|}{ Ketuban Pecah Dini } & \multirow{2}{*}{\multicolumn{2}{|c|}{ Total }} \\
\hline & & \multicolumn{2}{|c|}{ Aterm } & \multicolumn{2}{|c|}{ Preterm } & & \\
\hline & & $\mathrm{n}$ & $\%$ & $\mathrm{~N}$ & $\%$ & & \\
\hline 1. & Primipara & 6 & 100 & 0 & 0 & 6 & 100 \\
\hline 2. & Multipara & 10 & 83,3 & 2 & 16,7 & 12 & 100 \\
\hline 3. & $\begin{array}{l}\text { Grande } \\
\text { multipara }\end{array}$ & 0 & 0 & 2 & 100 & 2 & 100 \\
\hline & Jumlah & 16 & & 4 & & 20 & \\
\hline
\end{tabular}

Pada Tabel 4 menunjukkan bahwa dari 6 ibu melahirkan yang mengalami kejadian Prematur Rupture of Membrane Di Rumah Sakit Islam Garam Kalianget Pada tahun 2016 yang status paritasnya Primipara seluruhnya mengalami ketuban pecah dini pada usia kehamilan aterm, dan dari 12 ibu melahirkan yang mengalami kejadian Prematur Rupture of Membrane Di Rumah Sakit Islam Garam Kalianget Pada tahun 2016 yang status paritasnya multipara, sebagian besar yaitu 10 orang $(83,3 \%)$ mengalami Prematur Rupture of Membrane dalam usia kehamilan aterm dan 2 orang $(16,7 \%)$ diantaranya mengalami ketuban pecah dini dalam usia kehamilan preterm. Sedangkan dari 2 ibu melahirkan yang mengalami Prematur Rupture of Membrane Di Rumah Sakit Islam Garam Kalianget Pada tahun 2016 yang status paritasnya grande multi seluruhnya mengalami Prematur Rupture of Membrane pada usia kehamilan preterm.

5. Tabulasi silang Antara Letak Janin dengan Prematur Rupture of Membrane

Tabel 5. Tabulasi Silang Antara Letak Janin dengan Prematur Rupture of MembranePada
Ibu Melahirkan Di Rumah Sakit Islam Garam Kalianget Pada tahun 2016

\begin{tabular}{|c|c|c|c|c|c|c|c|}
\hline \multirow{3}{*}{ No } & \multirow{3}{*}{ Paritas } & \multicolumn{4}{|c|}{ Ketuban Pecah Dini } & \multirow{2}{*}{\multicolumn{2}{|c|}{ Total }} \\
\hline & & \multicolumn{2}{|c|}{ Aterm } & \multicolumn{2}{|c|}{ Preterm } & & \\
\hline & & $\mathrm{N}$ & $\%$ & $\mathrm{~N}$ & $\%$ & & \\
\hline 1. & $\begin{array}{l}\text { Bukan } \\
\text { kepala }\end{array}$ & 2 & 50 & 2 & 50 & 6 & 100 \\
\hline 2. & kepala & 16 & 100 & 0 & 16,7 & 12 & 100 \\
\hline & nlah & 18 & & 2 & & 20 & \\
\hline
\end{tabular}

Tabel 5 menunjukkan bahwa dari 4 ibu melahirkan yang mengalami Prematur Rupture of Membrane Di Rumah Sakit Islam Garam Kalianget Pada tahun 2016yang janinnya bukan letak kepala, separuhnya mengalami Prematur Rupture of Membrane dalam usia kehamilan yang aterm yaitu sebanyak 2 orang (50\%) dan separuhnya separuhnya mengalami ketuban pecah dini dalam usia kehamilan yang preterm yaitu sebanyak 2 orang (50\%) sedangkan dari 16 ibu melahirkan yang mengalami Prematur Rupture of Membrane Di Rumah Sakit Islam Garam Kalianget Pada tahun 2016 yang janinnya letak Janinnya adalah kepala seluruhnya mengalami Prematur Rupture of Membrane dalam usia kehamilan yang aterm yaitu sebanyak 16 orang (100\%).

\section{PEMBAHASAN}

\section{Status Paritas Pada Ibu Melahirkan yang Mengalami Prematur Rupture of Membrane}

Berdasarkan hasil penelitian yang telah dilakukan dapat dilihat bahwa sebagian besar ibu melahirkan yang mengalami Prematur Rupture of Membrane di Rumah Sakit Islam Garam Kalianget tahun 2016 adalah ibu multipara sebanyak 12 orang $(60 \%)$. Paritas adalah status seorang ibu yang dilihat dari berapa kalikah ibu melalui kehamilan hingga janin dapat bertahan hidup setelah dilahirkan di luar rahim. (JHPIEGO, 2008).

Geri Morgan dkk, (2009) menyatakan bahwa paritas termasuk salah satu faktor yang dapat memungkinkan terjadinya Prematur Rupture of Membrane yang dikarenakan dengan semakin seringnya ibu mengalami kehamilan akan memungkinkan kurang kuatnya jaringan ikat selaput ketuban selama proses kehamilan sebelumnya.

Hasil penelitian ini sesuai dengan teori Menurut Manuaba (2008) yang menyatakan 
bahwa salah satu penyebab dari ketuban pecah dini adalah multipara, dimana Pada seorang ibu yang berstatus multipara, jaringan ikat yang bertugas untuk menyangga membran ketuban mengalami penurunan sehingga selaput ketuban akan mudah pecah. Oleh karena itu ibu yang berstatus multipara lebih beresiko mengalami Prematur Rupture of Membrane (ketuban pecah dini) dibandingkan primipara.

\section{Letak Janin Pada Ibu Melahirkan Yang Mengalami Prematur Rupture of Membrane.}

Berdasarkan hasil penelitian di dapatkan bahwa hampir seluruhnya ibu melahirkan yang mengalami Prematur Rupture of Membrane Di Rumah Sakit Islam Garam Kalianget Pada tahun 2016 letak janinnya adalah letak kepala yaitu sebanyak16 orang (80\%).

Hasil penelitian ini tidak sejalan dengan teori yang dinyatakan oleh Nugroho (2010)yang mengatakan bahwa pada kelainan letak (selain letak kepala) menyebabkan tidak adanya bagian janin yang dapat menutupi bagian Pintu Atas Panggul (PAP) secara rapat seghingga dapat menghalangi adanya tekanan yang cukup besar pada membran dibagian bawah yang memudahkan pecahnya selaput ketuban janin.

Pada ibu melahirkan yang janinnya letak kepala seharusnya tidak rentan terhadap Prematur Rupture of Membrane karena pada letak kepala terdapat bagian terendah janin yang menututupi bagian bawah rahim. Faktanya pada hasil penelitian ini justru kejadian ketuban pecah dini hampir seluruhnya di alami oleh ibu yang janinnya letak kepala. hal ini menandakan ada kesenjangan antara teori dengan hasil penelitian.

Setelah di teliti lebih lanjut hasilnya adalah dari 16 ibu yang janinnya letak kepala selurunya bekerja sebagai ibu rumah tangga. Seorang ibu hamil yang bekerja terlalu beratdengan intensitas kerja yang melebihi 3 jam dalam sehari dapat menyebabkan kelelahan pada ibu. Kelelahan dalam bekerja inilah yang pada akhirnya menyebabkan lemahnya selaput ketuban sehingga mudah untuk pecah.

\section{Kejadian Prematur Rupture of Membraneberdasarkan usia kehamilan.}

Berdasarkan hasil penelitian di dapatkan bahwa hampir seluruhnya ibu melahirkan yang mengalami Prematur Rupture of Membrane Di Rumah Sakit Islam Garam Kalianget Pada tahun 2016 terjadi pada usia kehamilan aterm yaitu sebanyak 16 orang $(80 \%)$.

Hasil penelitian ini sesuai dengan yang disampaikan oleh teori Manuaba(2008), dimana dari seluruh angka kejadian Prematur Rupture of Membrane yang dilaporkan, lebih banyak terjadi pada ibu yang hamil aterm dari pada kehamilan preterm.

Ketuban pecah dini sangat berpengaruh terhadap angka kesakitan dan kematian perinatal serta terjaninya infeksi pada ibu (Sarwono, 2008), dimana kurang lebih ada $85 \%$ kesakitan dan kematian perinatal disebabkan karena prematuritas dan Prematur Rupture of Membrane berhubungan erat 3040\%dengan insidensi prematuritas.

Semakin rendah angka kejadian ketuban pecah dini yang terjadi dalam usia kehamilan aterm maka angka prematuritas yang di sebabkan oleh ketuban pecah dini juga akan semakin kecil.

\section{Hubungan Paritas dengan Kejadian Prematur Rupture of Membrane}

Berdasarkan hasil tabulasi silang menunjukkan bahwa dari 12 ibu melahirkan yang mengalami Prematur Rupture of Membrane Di Rumah Sakit Islam Garam Kalianget Pada tahun 2016 yang status paritasnya multipara, sebagian besar yaitu 10 orang $(83,3 \%)$ mengalami Prematur Rupture of Membrane dalam usia kehamilan aterm dan 2 orang $(16,7 \%)$ diantaranya mengalami Prematur Rupture of Membrane dalam usia kehamilan preterm.

Menurut Manuaba (2008) salah satu penyebab dari ketuban pecah dini adalah multipara, dimanaPada seorang ibu yang berstatus multipara, jaringan ikat yang bertugas untuk menyangga membran ketuban mengalami penurunan sehingga selaput ketuban akan mudah pecah. Sejalan dengan Hasil penelitian ini, penelitian yang di lakukan oleh Aiman pada tahun 2008 juga menyatakan bahwa pada multipara lebih banyak 
mengalami ketuban pecah dini dalam usia kehamilan aterm dari pada usia kehamilan yang preterm. Berdasarkan uraian pembahasan di atas dapat diambil kesimpulan bahwa Hipotesis pada penelitian ini adalah terbukti kebenerannya, sehingga dapat dikatakan bahwa "Paritas sebagai faktor resiko terjadinya Prematur Rupture of Membrane'karena semakin sering ibu menglami kehamilan maka akan memberikan risiko kesukaran dalam proses persalinan lebih besar termasuk salah satunya adalah Prematur Rupture of Membrane.

\section{Hubungan Kelainan letak dengan kejadian Prematur Rupture of Membrane}

Berdasarkan hasil tabulasi silang menunjukkan bahwa dari 16 ibu melahirkan dengan Prematur Rupture of Membrane Di Rumah Sakit Islam Garam Kalianget Pada tahun 2016 yang janinnya letak kepala seluruhnya mengalami ketuban pecah dini dalam usia kehamilan yang aterm yaitu sebanyak 16 orang (100\%).

Hasil penelitian ini di dukung dengan penelitian yang pernah di lakukan oleh Septy pada tahun 2010 dimana pada ibu hamil dengan posisi janinnya letak kepala lebih banyak mengalami Prematur Rupture of Membrane pada usia kehamilan aterm dibandingkan dengan usia kehamilan yang preterm.

$\begin{array}{ccc}\text { Menurut } & \text { Nugroho } & (2010) \\ \text { kelainan letak } & \text { (selain letak kepala) }\end{array}$ menyebabkan tidak adanya bagian janin yang dapat menutupi bagian Pintu Atas Panggul (PAP) secara rapat seghingga dapat menghalangi adanya tekanan yang cukup besar pada membran dibagian bawah yang memudahkan pecahnya selaput ketuban janin.

Faktanya pada penelitian ini ibu melahirkan yang mengalami Prematur Rupture of Membrane hampir seluruhnya letak janinnya letak kepala. Pada ibu hamil yang posisi janinnya letak kepala seharusnya tidak mengalami ketuban pecah dini karena terdapat bagian terendah janin yang dapat menghalangi tekanan pada rahim bagian bawah, Jadi wajar jika pada ibu yang janinnya letak kepala seluruhnya mengalami ketuban pecah dini dalam usia kehamilan aterm.

\section{KESIMPULAN}

Hasil penelitian ini dapat memberikan kesimpulan bahwa :

1. Sebagian besar ibu melahirkan dengan Prematur Rupture of Membrane Di Rumah Sakit Islam Garam Kalianget Pada Tahun 2016 adalah Multipara.

2. Hampir Seluruhnya ibu melahirkan denganPrematur Rupture of Membrane Di Rumah Sakit Islam Garam Kalianget Pada Tahun 2016 letak janinnya adalah letak kepala .

3. Hampir seluruhnya ibu melahirkan dengan Prematur Rupture of Membrane Di Rumah Sakit Islam Garam Kalianget Pada Tahun 2016 terjadi pada usia kehamilan aterm.

4. Ada hubungan antara paritas dengan kejadian Prematur Rupture of Membrane Di Rumah Sakit Islam Garam Kalianget Pada Tahun 2016.

5. Tidak ada hubungan antara kelainan letak dengan kejadian Prematur Rupture of Membrane Di Rumah Sakit Islam Garam Kalianget Pada Tahun 2016.

\section{SARAN}

1. Bagi Responden

Diharapkan ibu bisa mengerti dan mengetahui faktor penyebab serta dampak dari ketuban pecah dini.

2. Bagi Institusi Pendidikan

Bagi institusi pendidikan dapat dikembangkan sebagai acuan bahan penelitian selanjutnya, serta sebagai bahan masukan dan informasi sehingga dapat meningkatkan kualitas penelitian selanjutnya.

3. Bagi Institusi Kesehatan

Diharap kantenaga kesehatan, khususnya bidan sebagai motivator dalam melaksanakan asuhan kebidanan harus bisa lebih meningkatkan perannya dalam memberikan penyuluhan tentang faktor dan dampak dari ketuban pecah dini.

\section{DAFTAR PUSTAKA}

Almatsier, (2009). Pengertian kehamilan http: //wwwdigilib. unimus.ac .id/files /disk1/106/ jtptunimus-gdl-ratnasepti7641-3babl Pdf. Diakses 12 April 2015 jam 11.00 wib 
Almatsier, (2009). Ketuban pecah dinihttp://wwwdigilib.unimus.ac.id/files /disk1/106/ jtptunimus-gdl-gilangsris 6719-2babl.pdf Diakses 12 April 2015 jam 10.00 wib

Almatsier, (2009). Faktor Ketuban pecah dinihttp://wwwdigilib.unimus.ac.id/file s/disk1/106/ jtptunimus-gdl-3186.pdf. Diakses 12 April 2015 jam 10.00 wib

Asha amelia. (2014). ketuban pecah dini. http://www.sehatsatu.comdiakses tanggal 28 februari 2015 jam 16.00wib

Dennis. (2012). Karya tulis ilmiah akbid. http://www.dennistomby.blogspot.comd i akses tanggal 15 maret 2015 jam 11 $.00 \mathrm{wib}$

Dewi. (2014). Makalah ketuban pecah dini. http://www.dwinugraheni.blogspot.com di akses tanggal 15 maret 2015 jam 11 $.00 \mathrm{wib}$

Fauziyah, Yulia.

obstetri patologi.Yogyakarta : Nuha Medika

Hanung. (2013). Jurnal kebidanan Ketuban pecah

dini. http://www.hanungdyah.blogspot.comd i akses tanggal 15 maret 2015 jam 11 $.00 \mathrm{wib}$

Ica. (2012). kelainan letak lintang pada ibu hamil. http://www.bidan.comdiakses tanggal 15 Maret 2015 jam 16.00 wib

Indriawati. (2010). ketuban pecah dini. http://filekebidanan.blogspot.comdiaks es tanggal 28 februari 2015 jam 13.00wib

Kurniawati, (2012). ketuban pecah dini.http://www.adekuriawati.blogspot. comdi akses tanggal 15 maret 2015 jam $17.00 \mathrm{wib}$

Laily. (2010). Ketuban pecah sebelum waktunya.

http://www.adekuriawati.Blogspot.com di akses tanggal 15 maret 2015 jam 11 .00 wib

Hanung. (2013). Jurnal kebidanan Ketuban pecah dini. http://www.hanungdyah. blogspot.com di akses tanggal 15 maret 2015 jam $11.00 \mathrm{wib}$
Manuaba, Ide Ayu Chandranita, dkk. (2010) Ilmu Kebidanann, Penyakit Kandungan, dan KBuntuk Pendidikan Bidan. Jakarta : EGC

Manuaba, Ida Bagus Gede,dkk. (2007) Pengantar Kuliah Obstetri, Jakarta: EGC

Marlina, (2013). faktor-faktor yang berhubungan dengan ketuban pecah dini.http://www.marlinasanomm.blogsp ot.comdi akses tanggal 15 maret 2015 jam 20.00 wib

Mitha. (2011). kti ketuban pecah dini. http://mithaazone.blogspot.comdiakses tanggal 25 februari 2015 jam 13.00 wib

Morgan, Gery. (2009) Obstetri dan Ginekologi, Jakarta :EGC

Nugroho,Taufan. (2012) Patologi kebidanan, Yogyakarta : Nuha Medika

Notoadmodjo, Soekidjo. (2010) Metodologi Penelitian Kesehatan, jakarta: Rineka Cipta.

Prawirohardjo, Sarwono. (2009) Ilmu kebidanan, Jakarta : Bina pustaka

Septy. (2010). Ketuban pecah dini. http://www.phiphikuning.blogspot.com di akses tanggal 15 maret 2015 jam 11 $.00 \mathrm{wib}$

Saryono, Ari setiawan. (2011) Metodologi Penelitian Kebidanan, Yogyakarta : Nuha Medika

Sisiliya.(2013). Makalah ketuban pecah dini.http://www. sisiliya.blogspot.comdi akses tanggal 15 april 2015 jam 17.00 wib. 